\title{
Gender, sexuality, and violence in humanitarian crises
}

Dorothea Hilhorst Professor of Humanitarian Aid and Reconstruction, International Institute of Social Studies, Erasmus University Rotterdam, Netherlands, Holly Porter Marie Skłodowska-Curie Fellow, Institute of Development Policy (University of Antwerp) and Conflict Research Group (Ghent University), and Research Fellow, Firoz Lalji Centre for Africa, London School of Economics and Political Science, United Kingdom, and Rachel Gordon Independent research consultant, former SLRC researcher, Feinstein International Center, Tufts University, United States

Gender, sexuality, and violence have attracted significant attention in the sphere of humanitarianism in recent years. While this shift builds on the earlier 'Gender and Development' approach and the 'Women, Peace, and Security Agenda', analytical depth is lacking in practice. Notably, 'gender' often means a singular concern for women, neglecting questions of agency and the dynamic and changing realities of gendered power relations. This introductory paper examines why this neglect occurs and proposes a more relational approach to gender. It explores how the contributions to this special issue of Disasters revisit classic gender issues pertaining to violence, livelihoods, and institutions in different settings of humanitarian emergencies, while expanding one's vision beyond them. It draws from the seven papers a number of lessons for humanitarianism, concerning the entangled nature of gender relations, the risks of the unintended effects of gender programming, and the importance of paying sustained attention to how gender relations unfold in a time of crisis.

Keywords: gender relations, humanitarianism, sexuality, violence, women, World Humanitarian Summit

\section{Introduction}

One of the five key areas of action identified by the United Nations (UN) World Humanitarian Summit (WHS) in Istanbul, Turkey, on 23-24 May 20I6 was to 'achieve greater gender equality and greater inclusivity'. The WHS marked a new prominence of gender, and in particular of women and girls, in humanitarian aid. According to a report issued in the wake of the gathering, '[g] ender equality and women and girls' empowerment emerged as an overarching theme of the Summit with nearly $20 \%$ of all commitments addressing gender issues' (WHS, 20I6, p. 5). In addition, the High-Level Leaders' Roundtable on Women and Girls: Catalyzing Action to Achieve Gender Equality prompted 446 commitments. The report underlines that ' $[\mathrm{t}]$ his strong emphasis on gender reflects a firm desire for the World Humanitarian Summit to serve as a watershed moment whereby real change is achieved so that the needs of women and girls are systematically met and how [sic] their roles as decisionmakers and leaders are vigorously promoted' (WHS, 20I6, p. 6). 
That the humanitarian field was able to declare a watershed moment in terms of gender in 2016 is quite remarkable, because it came more than four decades after the formal declaration of attention to women in development. The 'Women in Development' approach that emerged in 1975 accorded prominence to the issues of women and girls with the double aim of enabling women's economic empowerment and tapping into the productive resources of women. This notion of 'women in development' has not disappeared from policy, but it has been criticised and overtaken by two successive paradigms: 'Women and Development', taking a more integrated view of women's productive, reproductive, and social roles in development; and 'Gender and Development', emphasising the social roles of both men and women, and addressing gender inequality.

Relatedly, the UN Security Council has passed a series of resolutions- I325, I820, I888, I889, I960, 2106, 2122, and 2242- on the role of women and girls in armed conflict. They are commonly described as having four pillars: participation; prevention; protection; and relief and recovery. Collectively, these are known as the 'Women, Peace, and Security (WPS) Agenda'. Major concerns of the resolutions pertain to active roles for women and girls in peacebuilding processes and in addressing conflictrelated sexual violence, both of which are subject areas that have been marginalised historically (Chinkin, 2002). The resolutions marked a major step forward in putting women's rights on the peace and security agenda of the UN and beyond. Indeed, as Tryggestad (2009) points out, the agenda is an expression of a 'new norm in the making'. Furthermore, Otto (20I0) notes how in addition to prompting a high level of institutional activity in the UN, the agenda has inspired many local and global women's movements for change.

Those involved in the drafting of these resolutions have always been explicit that the agenda should not be about making war safe for women. However, as they have been translated into national action plans for member states, those most active in humanitarian interventions have tended to do precisely this (Shepherd, 20I6a). Other critical assessments highlight the dominance of a very narrow concern for legal accountability of conflict-related sexual violence at the expense of other serious challenges (Aroussi, 20II; Engle, 20I4). More fundamentally, the framing and representation of 'women' on the agenda may have the troubling effect of entrenching the very gender binaries that feminist scholarship sees as the root causes of injustice and violence (Otto, 20IO; Shepherd, 20I6b), not to mention the persistent neglect of LGBT (lesbian, gay, bisexual, and transgender) concerns in conflict-related environments on the WPS Agenda and in subsequent related activism (Hagen, 20I6). It can only be incomplete, therefore, to talk about a Women, Peace, and Security Agenda. Instead there is a need for a Gender, Peace, and Security Agenda. Such a shift is far from straightforward, and is not without controversy. There is an understandable fear of reversing many of the gains of decades of international feminist activism and minimising the strategic utility of the existence of international frameworks and instruments that use the language of women and girls. Ultimately, to continue to do so is strategically essentialist - and the strategy clearly has mixed consequences for gender relations. 
The concept of gender moves away from viewing men and women as binary and separate categories, and instead is relational. A classic definition of gender states that it pertains to:

The differences between women and men within the same household and within and between cultures that are socially and culturally constructed, and change over time. These differences are reflected in: roles, responsibilities, access to resources, constraints, opportunities, needs, perceptions, views, etc. held by both women and men. Thus, gender is not a synonym for women, nor is it simply adding men, but considers both women and men and their interdependent relationships (Moser, I993).

More recent literature, taking into account LGBTQI (lesbian, gay, bisexual, transgender, queer or questioning, and intersex) communities, seeks to understand gender beyond the binary categories of men and women. It is concerned with 'the set of distinctions between different categories of people' and the ways in which gender labels 'valorize some [categories] over others, and organize access to resources, rights, responsibilities, authorities and life options along the lines demarcating these groups' (Cohn, 20I3, p. 4). Structural power relations are at the heart of gender studies (Cohn, 2013), and gendered vulnerabilities also are embedded in social norms, and related expectations. Whereas the gender paradigm is now widely referred to in the framing of development policy, development practices - and humanitarian action even more so-often slip into assuming (and employing operational categories dependent upon) binary essences, rather than engaging with ever-changing relations of power.

There is a large and rich scholarship on gender, sexuality, and violence in relation to conflict, disasters, and forced displacement. The extent to which the findings of this literature make their way into humanitarian policy and programming, though, is uneven. All of the papers in this special issue of Disasters concentrate on gender in settings that constitute humanitarian crises. They all examine areas that are, or have been until recently, dense with humanitarian action: the Democratic Republic of the Congo (DRC), Lebanon, northern Uganda, Somalia, South Sudan, and the refugee route from Syria to Greece. The seven papers address the gendered impacts of humanitarian interventions from different dimensions. In some of the papers, these interventions are the direct topic of investigation; in others, they loom in the background while their effects are felt in the ways in which women and men negotiate their roles and find spaces to manage their lives in challenging settings. Together, the collection provides food for thought for the humanitarian community and highlights themes and issues that are crucial to humanitarian interventions.

\section{Continued reductionism of 'gender' to women victims}

Given the framing of gender during the WHS, as well as the nature of the high-level leaders' roundtable, it appears that, despite decades of gender-focused research and learning, the humanitarian community still has a tendency to say 'gender', when in 
practice it means women and girls. Moreover, the spotlight is narrow, essentially focusing on the status of women and girls as vulnerable people or victims without agency.

An explanation of this proclivity is to be found in three key factors that intertwine the logics of aid delivery and the politics surrounding aid. The first is the needsbased character of much humanitarian aid. In seeking to assist the most vulnerable people, humanitarian actors seem to have a natural affinity for women writ large. Women are deemed homogenously more vulnerable than men, and are more associated with victimhood. Around the turn of the twenty-first century, literature emerged demonstrating the heightened vulnerability of women to 'natural' disaster (Enarson and Morrow, I998; Fordham, 2004). In conflict settings, the division of labour in which men are seen as aggressors and combatants whereas women are seen as non-combatant victims continues to limit gender notions in aid. This depiction is grounded in many sad empirical realities, yet it obscures other realities in which men and women assume the opposite-or more complex-roles, leading to a kind of tunnel vision that only centres on the suffering of women.

The occurrence of gender-based violence (GBV) in conflict has portrayed women as the primary victims of conflict, while less consideration has been given to the ways in which violence targets and involves men based on their gender. The special attention to women in conflict accelerated after the Fourth World Conference on Women in Beijing, China, on 4-I5 September 1995, where testimonies from women who were raped during the wars in the Balkans created a global constituency determined to tackle violence against women. Women make up the great majority of victims of conflict-related sexual violence-but certainly not all of them-while men are much more likely to be killed or maimed as a direct result of fighting. A classic example is the Srebrenica massacre in Bosnia-Herzegovina in July I995, where more than 8,000 Muslim Bosniak men and boys were murdered because of their gender; in this case, the humanitarian priority of female evacuation set the stage for the genocide. A more contemporary instance of such gendered (male-targeted) violence is the drone attacks carried out as part of the War on Terror, which have been criticised as indiscriminately targeting men in strike zones based on an assumed equivalency of maleness and militancy (Acheson, Moyes, and Nash, 20I4). As Dorothea Hilhorst and Nynke Douma discuss in this special issue of Disasters, rape and other forms of GBV have, however, attracted much more interest, and at times have become the dominating narrative of conflict-related suffering, such as during and after the wars in the DRC (see also Auteserre, 2012).

The inclination of agencies to view women as the primary victims and primarily as victims leads to many 'rhetorical inconsistencies' in descriptions of and approaches to humanitarian relief (Carpenter, 2005, p. 296). That there are many women-headed households among refugees, for instance, is only seen as yet another example of women's primary victimhood, with women having to bear lone responsibility for their families, without recognition of the fact that, in many of these households, men are missing because they were killed in conflict. Carpenter (2005, p. 297) contends that these inconsistencies are upheld because of a gender-essentialist view that 'all the women are victims, all the men are militias' (see also Enloe, I999). Even though 
multiple studies have highlighted the inaccuracy of this assumption and the particular experiences of female combatants (McKay and Mazurana, 2004; Moghadam, 2008; Coulter, 2009), this frame resonates with the 'moral language' familiar to international donors, and continues to dominate policy discussions and journalistic representations of the effects of war. This is especially poignant in the humanitarian domain where a foundational principle is the distinction between civilians and combatants.

The second, and associated, factor is the tendency to seek 'smart' solutions for humanitarian service delivery, where relief builds on local capacities. Women are widely assumed, due to naturally or socially determined characteristics, to be more nurturing and altruistic than men. Indeed, numerous development studies suggest that the impacts of aid on household welfare are dependent on whether the beneficiaries are male or female. Humanitarian programming targeting children or families thus often works through women. Women are frequently the designated recipients of access to healthcare, food aid, and microfinance. They are assumed to be more likely not to use available resources just for themselves, but also for the benefit of children or other vulnerable people in their care, such as the disabled, elderly, or sick. Studies show, for instance, that targeting cash transfers at women leads to greater improvements in child nutrition and health (Haddad, Hoddinott, and Alderman, I997; Handa and Davis, 2006).

Despite evidence of this gendered differential, operationalising norms of women as essentially more nurturing than men is problematic for myriad reasons (Molyneux, 2006). For one, this penchant may increase the burdens placed on women-not only the proverbial 'double burden' of supporting the household through paid and unpaid labour, but also, in extreme contexts, the expectation that women essentially will facilitate humanitarian programming 'on the cheap' (Chant and Sweetman, 20I2). In addition, it may be conceived as discriminatory towards men and as inattentive to the effects on gender relations more broadly. Turner (I999, p. 2) found refugees lamenting that 'UNHCR [United Nations High Commissioner for Refugees] is a better husband'. He describes how young men in refugee camps felt emasculated in a situation where international aid agencies supplied services through women, dispossessing men of their role as provider. As other scholars have shown, often this providing role of men is central to fulfilling social roles, particularly expectations of intimate relationships and marriage (Hunter, 20I0). The paper by Holly Ritchie in this special issue, and other recent studies on refugee livelihood programmes, underline these concerns, and reveal the ways that agencies acting on the assumption that women are the only carers in the household continue to entrench and naturalise it, turning the notion into a self-fulfilling prophecy.

While humanitarian aid in conflict-affected areas could once be characterised as purely needs-based and hands-on, international aid in protracted crises has increasingly become an amalgam of different interventions with different mandates and objectives, which may or may not fit neatly into the frame of humanitarianism. In addition to the focus on women as victims and preferred recipients of assistance, aid frequently is imbued with the aim of achieving greater gender equality, or at least ensuring that aid is not eroding the position of women, and maximising opportunities 
to promote more equal gender relations. UNHCR, in the case analysed by Turner (I999), had the explicit goal of promoting gender equality. The United Nations Children's Fund (UNICEF) likewise considers engaging women in service delivery as a positive step towards promoting women's rights, and describes it as the 'double dividend of gender equality' (UNICEF, 2006).

Greater attention to GBV has compounded the desire to promote women's rights in humanitarian programming. In many of the sites where the contributing authors carried out their research, from northern Uganda to the Kakuma Refugee Camp in Kenya and urban Bukavu in the DRC, there are visible markers of this trend: billboards, posters, and t-shirts remind men that they should not abuse women. Much can be said about these campaigns, yet we wish to highlight one adverse consequence: 'the responsibility of rights abuses are relocated away from national politics, international duty-bearers, and from the agencies as proxy authorities, towards individual men as violators of women's rights' (Hilhorst and Jansen, 20I2, p. 90I). Without denying the crucial importance of promoting women's rights, it is undeniable that these programmes can be seen simultaneously as expressions of the 'spurious logic through which Western imperial power seeks to justify its geopolitical domination by posing as the "liberator" of indigenous women from native patriarchal cultures' (Mahmood, 2009, p. I93). Indeed, interventions that, at least partially, are justified by the 'woman question' have a long history (Abu-Lughod, 2002).

The third key factor that reinforces the narrow and essentialist focus in the humanitarian field on women and women's rights is to be found in the realities of programme implementation, where women effectively advance their status of victim to enable their access to aid - a kind of strategic essentialism. Utas (2005) has labelled this practice 'victimcy', an expression of agency whereby women foreground their victimhood and downplay other aspects of their identity, including their political agency, to meet social expectations, which, in turn, yield a perceived benefit. Similarly, women often emphasise their roles as mothers or their supposedly inherent peaceful nature in their engagement in peace movements. In a complementary enactment of 'ignorancy' (Hilhorst, 20I6), aid workers on the ground are likely to play along with this representation in their reports to headquarters and donors in order to secure the continued provision of aid. Roxanne Krystalli, Allyson Hawkins, and Kim Wilson, in this special issue of Disasters, give an example in which aid workers actively teach women about effectively presenting themselves as victims of GBV before they enter asylum procedures. Similarly, Julian Hopwood, Holly Porter, and Nangiro Saum, also in this special issue, suggest that, in a search for eligibility, people try to discern and manifest the characteristics that will position them as 'ideal recipients' of aid. The (understandable) pragmatic choices of women and aid workers on the ground can thus perpetuate the essentialist presentation and representation of women as victims and preferred aid recipients.

This imaginary of women as victims and preferred aid recipients is rarely openly contested, and is not noticeably diversified, in humanitarian policy. It is interesting to discuss at length, therefore, one of the rare occasions when such a public discussion 
did take place. The International Review of the Red Cross published an opinion note by Chris Dolan in 20I4 that argued for the replacement of the goal of gender equality with a 'gender inclusivity' paradigm (Dolan, 20I4). In a response, Jeanne Ward (20I6), a lead author of the Guidelines for Integrating Gender-based Violence Interventions in Humanitarian Action (IASC, 2015), maintained that a gender equality paradigm and specific attention to women remains important.

Dolan produced the opinion note at the time that the Guidelines for Gender-based Violence Interventions in Humanitarian Settings: Focusing on Prevention of and Response to Sexual Violence in Emergencies (IASC, 2005) were being rewritten, and emphasised that they should promote a more gender inclusive framework: 'the range of victims and survivors that are not just recognized but also addressed needs to be more inclusive - most urgently male and lesbian, gay, bisexual, transgender and intersex (LGBTI) victims and survivors - and a range of non-sexual forms of GBV must also become the target of humanitarian attention' (Dolan, 20I4, p. 486). He proposed that, ' $[\mathrm{t}]$ o reverse the current malfunction of gender as an analytical, practical and political engine, we must replace women and girls as the default at-risk group with more gender-inclusive formulations' (Dolan, 20I4, p. 500).

Yet, in her response, Ward (20I6) asserted that attention to women is still key. As the title of her response states: 'it is not about the gender binary, it's about the gender hierarchy'. She quoted the introduction of the Guidelines for Integrating Genderbased Violence Interventions in Humanitarian Action (IASC, 20I5) to underline that:

Women and girls everywhere are disadvantaged in terms of social power and influence, control of resources, control of their bodies and participation in public life - all as a result of socially determined gender roles and relations. Gender-based violence occurs in the context of this imbalance. While humanitarian actors must analyse different gendered vulnerabilities that may put men, women, boys and girls at heightened risk of violence and ensure care and support for all survivors, special attention should be given to females due to their documented greater vulnerabilities to GBV, the overarching discrimination they experience, and their lack of safe and equitable access to humanitarian assistance (Ward, 20I6, p. 28I (emphasis in the original)).

The conversation between Dolan and Ward yields interesting perspectives, but it does not disrupt markedly the discourse whereby women and men are boxed into separate and rather stagnant categories, either binary or hierarchical. By prioritising these categorical issues, the debate may miss the mark regarding gender as relations of power that, like everything else, are cast into disarray during humanitarian crises. Gender relations are deeply ingrained in, and reproduced by, the working of all institutions in society, ranging from the personal between men and women to the working of cultural values, geopolitics, governance practices, and religion. Moreover, the large body of literature on intersectionality demonstrates how gender interrelates with class, ethnicity, and other social identity markers. The ways in which these gendered institutions continue, discontinue, alter, or bounce back before, during, 
and after crises are complex and dynamic. The critical questions here are: how do humanitarian responses interact with these myriad aspects of gender and other interrelated social identities? And how do humanitarian responses thus affect gender relations? One of the recurring themes in this special issue of Disasters is that aid may have powerful and immediate effects on gender relations in the context of intervention. How these effects interact with ongoing processes of change, and how they work out in the long term, are matters that come to the fore in the seven papers that follow this introductory essay.

The papers continue to explore some of the classic issues in feminist reflection, including livelihoods, sexual violence, and the ways in which women and men navigate the spaces accorded to them in political and social institutions. This special issue, though, seeks to expand our vision beyond these issues and to remove the essentialist lenses through which we might typically view them. The papers highlight the relational impacts of these issues and present the situations of women and men living in very difficult places in ways that nuance our understanding of their lives - their ability to exercise agency and the ways in which gender creates particular vulnerabilities to violence and the risk of harm. Each paper also conveys specific messages for humanitarian interventions in a crisis zone. The remainder of this essay highlights these messages.

\section{Content: shifting the conversation}

This special issue starts with two papers that concentrate on gender and refugees. Roxanne Krystalli, Allyson Hawkins, and Kim Wilson begin their submission by asking a very pertinent question: what would a gender analysis of refugee crises reveal if one expanded the focus beyond female refugees, and acts of physical violence? Drawing on qualitative research in Denmark, Greece, Jordan, and Turkey, the paper follows the gendered choices that refugees make on their journeys to find safety. One of the striking themes is how men and women take gender expectations into account when strategising how to overcome the perils of their crossing. For instance, while men retain the power to make decisions about how resources will be used, they ask women to carry money on their bodies as this is considered to be less risky. Another example is decisions about the order in which family members will travel to Europe; families will explore whether to send youths, men, or women ahead of other members to advance their chances of eventually uniting together at a preferred destination. The paper spotlights a central theme of this special issue: the ways in which gender relations change in a time of humanitarian crisis and how these shifts are partly due to actors engaging in crisis response, that is, aid agencies and governments. Of particular concern here is men and boys, as well as people fleeing outside of recognisable, heteronormative family units, being left off priority agendas by aid agencies. In addition, by focusing on monetary resources and decisions relating to money, the paper draws attention to another central theme of this special issue: intersectionality, and the importance of social hierarchies among refugees. 
Holly Ritchie's contribution centres on gender and enterprise in fragile refugee settings. The paper builds on work in Afghanistan and assesses women's enterprise and their negotiation of their social position among Somali refugees in Nairobi and Syrian refugees in Jordan. The paper's meticulous analysis reveals three fundamental aspects of gender, livelihoods, and interventions. First, it questions the widely-held idea that women's economic empowerment will translate into an improvement in their social position, contending that the economic position of women entrepreneurs is overwhelmingly precarious given the economic markets and the restrictions on negotiating their (heterogeneous) social position vis-à-vis their husbands and family members. The paper takes a welcome institutional perspective, and seeks to illustrate the ways in which culture and religion affect fragility and the space available to women to become successful entrepreneurs. Second, it describes how important women's collective action can be in advancing their position, even if it may appear to be small and mainly geared towards addressing only practical needs. Third, it develops the theme of how interventions may affect masculinity in ways that render men's prospects of finding meaningful occupations and fulfilling their socialised roles as household provider rather grim.

Three papers in this special issue concentrate on sexual violence and responses to it. All of them take a broader perspective towards understanding this subject matter, adding layers to humanitarian concern with addressing sexual violence in the midst of a crisis. The contribution by Teddy Atim, Dyan Mazurana, and Anastasia Marshak explores specifically one of the long-term consequences of conflict-related sexual violence: children born of war and the challenges to them and their mothers. Compellingly, their evidence suggests that the stigma that these women and children endure does not lessen over time-unlike the attention of humanitarian actors and international donors. Instead problems transform and amplify over time, especially as children grow up and have evolving needs in different phases of life. Perhaps one of the most troubling and intriguing findings of their research is that families with one or more members who experienced sexual violence during some two decades of violence and armed conflict (1986-2006) in northern Uganda were much more likely to have suffered other violent crimes in ordinary life in the years since the fighting ended. While the passage of time is not a critical factor in lessening social challenges and stigma facing these children and their families, Atim, Mazurana, and Marshak point the reader towards what is: being able to make an income. They demonstrate how an economic livelihood is key to meeting daily material needs, as well as being a crucial enabler of social mutuality. The authors found that women in their study were able to transform themselves via economic opportunities from being perceived burdens on their relatives and wider communities to being seen as (and actually being) contributing members of post-war society. Alarmingly, the research also revealed that much of the vocational training and other external aid intended for enabling economic empowerment was of little benefit to the intended beneficiaries, for a variety of reasons. 
The paper by Dorothea Hilhorst and Nynke Douma offers an evaluation of the response to conflict-related rape in eastern DRC over a six-year period. The paper is positioned in a stream of recent publications that discuss critically what they see as onesided and essentialising attention to sexual violence in the country, raising concerns that other priority issues are underserved. These publications assert that the response has triggered bias and malpractice, driving down popular sympathy for victims of GBV. Furthermore, the victim-orientation of the response boxes women into a stereotyped representation that denies their agency and life choices. Based on their own research and this literature pool, Hilhorst and Douma examine how the response generated by the pervasive issue of sexual violence turned to 'hype', as the narrative of sexual violence became overarching and inescapable over the course of a number of years. The paper theorises 'hypes', defining them as phenomena characterised by a media frenzy, eagerness by non-governmental organisations, and pragmatic local responses. The paper explores what happened after the hype. It arrives at the conclusion that, on the one hand, the essentialist approach to gender and violence gradually gave way to a broader approach with more space for women's agency and parallel priorities. On the other hand, however, this episode in eastern DRC resulted in a number of unintended consequences, especially in the legal and social domains. These merit a sector-wide analysis to learn how international interventions can tread more carefully in the delicate sphere of gender and violence. Lastly, the research of Hilhorst and Douma underlines how international interventions in the realm of gender and humanitarianism may be powerful in affecting gender hierarchies, albeit in ways that may be largely unintended and unplanned.

The paper by Alicia Elaine Luedke and Hannah Faye Logan shines a light on the connections between wartime sexual violence and the pervasive, 'everyday' forms of gendered violence and disempowerment in South Sudan. Their analysis demonstrates how wartime GBV, far from being an exceptional or anomalous occurrence, can be a logical extension of the 'normal' gender dynamics of the setting, and moreover how the hyper-masculine culture promoted by South Sudan's long-increasing militarism, along with its economic decline, exacerbates those dynamics. The authors critique the prevalent narrative of sexual violence as a 'weapon of war' in the South Sudan conflict, drawing on prominent discussions of the concept elsewhere in which that narrative, as well as its underlying assumptions, have been heavily problematised to illustrate the perverse consequences of the South Sudan aid community's tendency to divorce GBV during conflict from its contextual underpinnings. Longstanding and deeply rooted practices that claim ownership of women's bodies, particularly the payment of bride wealth, are exemplary, and perhaps the most entrenched factors giving rise to the violent assertion of male combatants' perceived rights to female bodies as loot-able property and contestable territory. For obvious reasons, Luedke and Logan point out that this situation is likely only to continue to worsen in tandem with the economic situation in the country. Thus, the narrow focus on conflictrelated sexual violence and recycled (although well-intentioned) responses to it by 
international organisations are not only unhelpful, but also often run counter to and undermine local norms, particularly when there is a power structure that is already suspicious of external intervention.

The final two papers in this special issue of Disasters continue the theme of how gender roles and relations change and persist throughout a crisis. Rebecca Tapscott's submission on northern Uganda provides a gender analysis of youth participation in informal security arrangements. It turns one's attention to the discrepancies between militarised and civilian masculinities and how these are used instrumentally by the state to govern men in a region recently emerging from war, with significant underemployment, and where the state still perceives the threat of (armed) political opposition to be an imminent possibility. Importantly, the analysis breaks with much of the literature on masculinity and violence, presenting instead a context where civilian and military 'ideals' of masculinity are in tension and even in competition with one another. The paper illustrates the socio-cultural aspects of participation in informal security arrangements and civilian militias, complicating what is frequently seen as a primarily politically motivated phenomenon. It suggests that the civilian masculine ideals of providing, protecting, and procreating are highly valued but often unattainable without alliance with a militarised state, and that aid interventions might do well therefore to pay more attention to diversifying and demilitarising the livelihood options available to young men in such settings.

Julian Hopwood, Holly Porter, and Nangiro Saum assess the rather improbable but drastic reported shift in gender relations in Karamoja, Uganda, between 20I I and 20I6. Their paper, however, demonstrates that this is most likely due to a superficial reduction in the worst excesses of gendered violence, enabled by ongoing food aid in the midst of famine. Even though there have been rather fundamental changes in gender roles as men have lost cattle and guns - central features of life in Karamojaand are now largely sedentary, the evidence put forward calls into question the ofthoped for transformative potential of moments of societal upheaval. Instead, it reveals that patriarchal norms are now expressed differently but still strongly as undercurrents to social order. It also highlights some of the easily overlooked gendered consequences of large aid interventions. Notably, the state policy of disarmament and the promotion of agriculture over pastoralism led to a shrunken space for female autonomy as men who were largely absent in the past were suddenly in more regular physical proximity to women. Furthermore, food distributions that target mothers in certain age brackets had the dual effect of driving pregnancy (frequently at a young age) and of allowing women to fulfil proscribed gendered roles of feeding the family, perhaps leading to a reduction in violence against them. The paper appraises the complications of institutional change, and cautions against a simplistic approach to institutions. The case of Karamoja suggests that interventions, especially when they enhance the material resource base of women, can result in improved daily gender relationships. It casts doubt, however, on this leading to longer-term or more fundamental changes. 


\section{Conclusion}

In summary, the seven contributions to this special issue of Disasters highlight the dynamic and entangled nature of gender relations. There are always multiple layers and facets of gender relations that produce different types of change, happening at different rates and moving in different directions - at times reinforcing and often negating or contradicting each other. The economic empowerment of women, for instance, may spill over positively into other domains of life, or contrarily undermine goodwill towards women's positions and bring about a violent backlash against them, as well as humanitarians. This tension is particularly prominent in crisis and conflict situations, where gender relations are (superficially and temporarily, or more deeply and enduringly) thrown into disarray, and taken-for-granted gender roles and ideologies become contentious and subject to revaluation.

The papers provide evidence of how humanitarian and political attention to gender adds additional layers to the complexities of gender relations in crisis environments. The politics of institutional change will affect gender relations in expected and unexpected ways, and even more so when they instrumentalise gender to reinforce authority or legitimise political change. All of the submissions deal with settings with a large density of aid programmes, and show how interventions often seek unidimensional change to the complex and entangled realities of gender. It is no surprise that this approach frequently has unintended consequences, instead of or in addition to those that are intended. This situation is further complicated by the perilous ways in which external interventions interact with local gender norms, seeking to build on local institutions to enhance their legitimacy without reproducing inequalities that may be embedded in these local institutions.

The wide-ranging manifestations of GBV in conflict-affected areas will continue to summon forth policy attempts to protect vulnerable women, men, and other gender categories, aiming to avoid harm while looking to contribute to positive change. A central lesson of this special issue is that policies need to pay sustained attention to how gender relations unfold in conflict-affected areas and to the intended and unintended effects of programmes.

\section{Acknowledgements}

This special issue is a joint initiative of the Secure Livelihoods Research Consortium (SLRC; PO5II2) and the Justice and Security Research Programme (JSRP; PO5729). The issue was funded by the UK's Department for International Development (DFID), and the Firoz Lalji Centre for Africa of the London School of Economics and Political Science (in particular through its Centre for Public Authority and International Development ES/Poo8038/I; the Politics of Return PaCCS/AHRC AH/Poo5454/I; and the Trajectories of Displacement ESRC ES/Poo49II/I).

We sincerely thank Bart Weijs and Sarah Pelham for their crucial support for the issue. We also thank Tim Allen, Tatiana Carayannis and Paul Harvey for their great efforts to make the issue happen, and Paul Kirby for his comments on this article. 


\section{Correspondence}

Dorothea Hilhorst, International Institute of Social Studies, Erasmus University Rotterdam, Kortenaerkade I2, 25I8 AX Den Haag, Netherlands.

Telephone: +3I 70426 o460; e-mail: hilhorst@iss.nl

\section{References}

Abu-Lughod, L. (2002) 'Do Muslim women really need saving? Anthropological reflections on cultural relativism and its others'. American Anthropologist. I04(3). pp. 783-790.

Acheson, R., R. Moyes, and T. Nash (2014) 'Sex and drone strikes - gender and identity in targeting and casualty analysis'. http://www.academia.edu/898I393/Sex_and_drone_strikes_-_gender_and_ identity_in_targeting_and_casualty_analysis (last accessed on I8 December 20I7).

Aroussi, S. (20I I) 'Women, peace and security: addressing accountability for wartime sexual violence'. International Feminist Journal of Politics. I3 (4). pp. 576-593.

Autesserre, S. (2OI2) 'Dangerous tales: dominant narratives on the Congo and their unintended consequences'. African Affairs. II I (443). pp. 202-222.

Carpenter, R.C. (2005) “"Women, children and other vulnerable groups”: gender, strategic frames and the protection of civilians as a transnational issue'. International Studies Quarterly. 49 (2). pp. 295-334.

Chant, S. and C. Sweetman (20I2) 'Fixing women or fixing the world? "Smart economics", efficiency approaches, and gender equality in development'. Gender and Development. 20(3). pp. 5I7-529.

Chinkin, C. (2002) 'Gender, human rights and peace agreements'. Ohio State Journal on Dispute Resolution. I8(3). pp. 267-286.

Cohn, C. (2013) Women and Wars: Contested Histories, Uncertain Futures. Polity Press, Cambridge.

Coulter, C. (2009) Bush Wives and Girl Soldiers: Women's Lives through War and Peace in Sierra Leone. Cornell University Press, Ithaca, NY.

Dolan, C. (2014) 'Letting go of the gender binary: charting new pathways for humanitarian interventions on gender-based violence'. International Review of the Red Cross. 96(894). pp. 485-50I. https://www.icrc.org/en/international-review/article/letting-go-gender-binary-chartingnew-pathways-humanitarian (last accessed on I I December 2017).

Enarson, E. and B.H. Morrow (1998) The Gendered Terrain of Disaster: Through Women's Eyes. Praeger, New York, NY.

Engle, K. (2014) 'The grip of sexual violence: reading UN Security Council resolutions on human security'. In G. Heathcote and D. Otto (eds.) Rethinking Peacekeeping, Gender Equality and Collective Security. Palgrave Macmillan, London. pp. 23-48.

Enloe, C. (1999) 'All the men are in the militias, all the women are victims: the politics of masculinity and femininity in nationalist wars'. In L.A. Lorentzen and J. Turpin (eds.) The Women and War Reader. New York University Press, New York, NY. pp. 50-62.

Fordham, M. (2004) 'Gendering vulnerability analysis: towards a more nuanced approach'. In G. Frerks, G. Bankoff, and D. Hilhorst (eds.) Mapping Vulnerability: Disasters, Development and People. Earthscan, London. pp. I74-I83.

Haddad, L.J., J. Hoddinott, and H. Alderman (1997) Intrahousehold Resource Allocation in Developing Countries: Models, Methods, and Policy. Johns Hopkins University Press, Baltimore, MD.

Hagen, J. (2016) 'Queering women peace and security'. International Affairs. 92 (2). pp. 313-332.

Handa, S. and B. Davis (2006) 'The experience of conditional cash transfers in Latin America and the Caribbean'. Development Policy Review. 24(5). pp. 513-536. 
Hilhorst, D. (2016) Aid-society Relations in Humanitarian Crises and Recovery. Inaugural lecture, presented on 22 September 20I6, in acceptance of the Chair of Humanitarian Aid and Reconstruction at the Institute of Social Studies of Erasmus University Rotterdam.

Hilhorst, D. and B. Jansen (20I2) 'Constructing rights and wrongs in humanitarian aid'. Sociology. 46(5). pp. 89I-905.

Hunter, M. (2010) Love in the Time of AIDS: Inequality, Gender, and Rights in South Africa. Indiana University Press, Bloomington, IN.

IASC (Inter-Agency Standing Committee) (2005) Guidelines for Gender-based Violence Interventions in Humanitarian Settings: Focusing on Prevention of and Response to Sexual Violence in Emergencies. https:// interagencystandingcommittee.org/system/files/legacy_files/tfgender_GBVGuidelines20o5.pdf (last accessed on i I December 2017).

IASC (2015) Guidelines for Integrating Gender-based Violence Interventions in Humanitarian Action: Reducing Risk, Promoting Resilience and Aiding Recovery. https://gbvguidelines.org/wp/wp-content/uploads/20I5/ 09/20I5-IASC-Gender-based-Violence-Guidelines_lo-res.pdf(last accessed on I I December 20I7).

Mahmood, S. (2009) 'Feminism, democracy, and empire: Islam and the War on Terror'. In H. Herzog and A. Braude (eds.) Gendering Religion and Politics: Untangling Modernities. Palgrave Macmillan, New York, NY. pp. I93-2I5.

McKay, S. and D. Mazurana (2004) Where are the Girls? Girls in Fighting Forces in Northern Uganda, Sierra Leone and Mozambique: Their Lives during and after War. International Centre for Human Rights and Democratic Development, Montreal.

Moghadam, A. (2008) The Globalization of Martyrdom: Al Qaeda, Salafi Jihad, and the Diffusion of Suicide Attacks. Johns Hopkins University Press, Baltimore, MD.

Molyneux, M. (2006) 'Mothers at the service of the new poverty agenda: progresa/oportunidades, Mexico's conditional transfer programme'. Social Policy and Administration. 40 (4). pp. 425-449.

Moser, C. (1993) Gender Planning and Development: Theory, Practice and Training. Routledge, London. Otto, D. (20Iо) 'Power and danger: feminist engagement with international law through the UN Security Council'. Australian Feminist Law Review. 32 (I). pp. 97-I2I.

Shepherd, L. (20г6a) 'Making war safe for women? National action plans and the militarisation of the women, peace and security agenda'. International Political Science Review. 37(3). pp. 324-335.

Shepherd, L. (20I6b) 'Victims of violence or agents of change? Representations of women in UN peacebuilding discourse'. Peacebuilding. 4(2). pp. I2I-I35.

Tryggestad, T. (2009) 'Trick or treat? The UN and implementation of Security Council Resolution I325 on women, peace, and security'. Global Governance. I5 (4). pp. 539-557.

Turner, S (1999) Angry Young Men in Camps: Gender, Age and Class Relations among Burundian Refugees in Tanzania. New Issues in Refugee Research. Working Paper No. 9. International Development Studies, Roskilde University, Roskilde.

UNICEF (United Nations Children's Fund (2006) The State of the World's Children 2007: Women and Children: The Double Dividend of Gender Equality. UNICEF, Geneva.

Utas, M. (2005) 'Victimcy, girlfriending, soldiering: tactic agency in a young woman's social navigation of the Liberian war zone'. Anthropological Quarterly. 78(2). pp. 403-430.

Ward, J. (20I6) 'It's not about the gender binary, it's about the gender hierarchy: a reply to "letting go of the gender binary". International Review of the Red Cross. 98(I). pp. 275-298. https://www.icrc. $\mathrm{org} / \mathrm{en} /$ international-review/article/its-not-about-gender-binary-its-about-gender-hierarchyreply-letting-go (last accessed on II December 20I7).

WHS (World Humanitarian Summit) (2016) Commitments to Action. http://agendaforhumanity.org/ sites/default/files/resources/20I7/Jul/WHS_commitment_to_Action_8September2oi6.pdf (last accessed on 6 December 20I7). 